\title{
Butenolides from Plant-Derived Smoke: Natural Plant-Growth Regulators with Antagonistic Actions on Seed Germination
}

\author{
Marnie E. Light, Ben V. Burger, Dan Staerk, Ladislav Kohout \& Johannes Van Staden
}

Research Centre for Plant Growth and Development, School of Biological and Conservation Sciences, University of KwaZulu-Natal Pietermaritzburg, Private Bag X01, Scottsville 3209, South Africa, Laboratory for Ecological Chemistry, Department of Chemistry, University of Stellenbosch, Stellenbosch 7600, South Africa, Department of Basic Sciences and Environment, Faculty of Life Sciences, University of Copenhagen, Thorvaldsensvej 40, DK-1871 Frederiksberg, Denmark, and Institute of Organic Chemistry and Biochemistry, Academy of Sciences of the Czech Republic, v.v.i., Flemingovo nám. 2, 16610 Prague 6, Czech Republic

\begin{abstract}
Smoke plays an intriguing role in promoting the germination of seeds of many species following a fire. Recently, a bicyclic compound containing a condensed butenolide moiety, 3-methyl-2Hfuro[2,3-c]pyran-2-one (1), was reported as a potent germination promoter from plant-derived smoke. In this study, a related butenolide, 3,4,5-trimethylfuran-2(5H)-one (2), which inhibits germination and significantly reduces the effect of 1 when applied simultaneously, was also isolated from plant-derived smoke. The interaction of these compounds with opposing actions on seed germination may have important ecological implications in a post-fire environment and could be useful molecules for understanding the events involved in breaking seed dormancy and promoting seed germination.
\end{abstract}

Smoke from burning vegetation is recognized as an important environmental cue and promoter of germination for seeds of many species from both fire-prone and non-fire-prone environments.(1) Smoke-water, prepared by bubbling smoke through a container of water, is also highly effective in promoting seed germination of the responsive species and is a more convenient method of treatment. The major germination compound responsible for the observed germination increase was isolated and identified as 3-methyl-2H-furo[2,3-c]pyran-2-one (1, karrikinolide), $(2,3)$ a discovery that has revealed a class of plant bioactive compounds that are referred to as karrikins(4) and are proposed to be a new and important family of naturally occurring plant growth regulators. $(5,6)$

Subsequently, $\mathbf{1}$ has been shown to improve germination and improve seedling vigor of several species, including those from fire-prone environments, arable and parasitic weeds, several Australian Solanum species, and crop plants.(5) Due to the fact that it has an effect at extremely low concentrations (as low as $1 \mathrm{nM}$ ), it has potential as an important agronomic and horticultural chemical. $(5,7)$ Although the mode of action of smoke and $\mathbf{1}$ (and related karrikins) in promoting germination and vigor is currently unknown, research is progressing in this field. $(4,8,9)$ Previous investigations of smoke-stimulated seed germination demonstrated that dilute solutions of smoke-water were highly effective in promoting the germination of light-sensitive seeds of Lactuca sativa L. cv. Grand Rapids.

Thus, Grand Rapids lettuce was used as an effective model species for bioactivity-guided fractionation of smoke-water. $(3,10)$ Although, in general, smoke provides a positive stimulus for germination, a negative effect of high concentrations of smoke-water on germination is well demonstrated.(10-13) This effect can most likely be attributed to inhibitory compounds (i.e., compounds other than the promotory karrikins) that are present in the smoke-water. Smoke (from cigarettes or other products) is known to contain numerous compounds (estimated to be well over 4000),(14) some of which are toxic or carcinogenic. In another study, it was reported that smoke could possibly play a dual regulatory role during germination,(15) providing the stimulus to germinate, but possibly preventing germination until sufficient water was available.

Such a dual signal system, involving both promotory and inhibitory compounds, could be important in post-fire environments. 
In our previous study on the isolation of the key germination promoter (1) from plant-derived smoke using bioactivity-guided fractionation,(3) it was observed that some fractions showed inhibitory activity in the germination assay. Germination levels for these fractions were $0 \%$, which was significantly $(P>0.05)$ lower than the control, which had a germination of $14.5 \pm 9.3 \%$. Further fractionation using HPLC and bioactivity-guided preparative GC led to the isolation of racemic 3,4,5trimethylfuran-2(5H)-one (2,3,4-trimethylbut-2-enolide) (2).

The structure was elucidated using GC-MS and NMR spectroscopy and confirmed by synthesis. The inhibitory action of $\mathbf{2}$ on germination was assessed by incubating the lettuce seeds with test solutions containing a combination of synthetic $1(0.001$ to $0.1 \mu \mathrm{M})$ with synthetic 2 (0.1 to $100 \mu \mathrm{M})$ (Figure 1). Results indicated that at 10 and $100 \mu \mathrm{M}$, compound $\mathbf{2}$ significantly reduced the promotive effect of compound $\mathbf{1}(0.001$ to $0.1 \mu \mathrm{M})$ when applied simultaneously. Application of $\mathbf{2}$ alone resulted in $0 \%$ germination at 10 and $100 \mu \mathrm{M}$, and at 0.1 and $1 \mu \mathrm{M}$ germination was not significantly different from the water control. Preparative enantioselective GC yielded practically pure samples of the two enantiomers of $\mathbf{2}$. It was found that the enantiomers are equally active germination inhibitors.

It is of great interest that the trisubstituted but-2-enolide ring is a common structural feature of compounds $\mathbf{1}$ and $\mathbf{2}$. This leads to the speculation that $\mathbf{2}$ may somehow block the action of promoter compound $\mathbf{1}$ or interact with a possible receptor related to the action of $\mathbf{1}$. Thus, the next step will be to conduct in-depth molecular biology studies on the interaction of these two compounds, adding a further dimension to the emerging picture on the effect of smoke on seed germination in fireprone environments. It is conspicuous that these small molecules as plant-derived smoke constituents have opposing actions on germination. In terms of a post-fire environment, it is most beneficial for seeds to germinate when there is sufficient light, nutrients, and water available. Thus, these bioactive butenolides are important environmental signal molecules for regulating the best emergence time for seeds following a fire.

\section{Experimental Section}

\section{General Experimental Procedures}

${ }^{1} \mathrm{H}$ and ${ }^{13} \mathrm{C}$ NMR spectra of 2 were acquired at a ${ }^{1} \mathrm{H}$ resonance frequency of $400.13 \mathrm{MHz}$ on a Bruker Avance 400 spectrometer equipped with a $1 \mathrm{~mm}$ probe at $25^{\circ} \mathrm{C}$. The sample of 2 was made up to 25 $\mu \mathrm{L}$ with methanol- $d_{4}$, and the residual solvent peak methanol- $d_{3}$ was used as internal reference for ${ }^{1} \mathrm{H}(\delta 3.31)$, whereas methanol- $d_{4}$ was used as internal reference for ${ }^{13} \mathrm{C}(\delta 49.9) .{ }^{1} \mathrm{H}$ and ${ }^{13} \mathrm{C} \mathrm{NMR}$ spectra of synthetic 2 were obtained with a Varian INOVA 600 NMR instrument at $25^{\circ} \mathrm{C}$. Residual $\mathrm{CHCl}_{3}$ with $\delta_{\mathrm{H}} 7.26$ and $\delta_{C} 77.04$ was used as internal standard. Semipreparative HPLC was performed using a reversed-phase column (Haisil, $300 \mathrm{C} 18,5 \mu \mathrm{m}, 250 \times 10 \mathrm{~mm}$, Higgins Analytical) with $30 \% \mathrm{MeOH}$ mobile phase at $2 \mathrm{~mL} / \mathrm{min}$. A Spectra System P4000 pump and UV6000LP photodiode array detector (Thermo Separation Products) were used. Analytical GC-MS analyses were carried out with a Carlo Erba QMD 1000 instrument consisting of a Trio 1 quadrupole mass spectrometer coupled to a CE 5300 gas chromatograph, using a column coated with PS-089 (DB-5 equivalent) $(40 \mathrm{~m} \times 0.3 \mathrm{~mm}$, df $0.35 \mu \mathrm{m})$, which was programmed from $40^{\circ} \mathrm{C}$ to $220^{\circ} \mathrm{C}$ at $4{ }^{\circ} \mathrm{C} / \mathrm{min}$ to monitor the fractionation of 2 . A column $(25 \mathrm{~m} \times 0.3 \mathrm{~mm})$ coated with $0.25 \mu \mathrm{m}$ of PS-089-OH containing $10 \%$ heptakis(2,3-di-O-acetyl-6-O-tert-butyldimethylsilyl)- $\beta$-cyclodextrin as chiral selector $\left(R_{\mathrm{s}}=10.5\right)$ was programmed from $40^{\circ} \mathrm{C}$ to $80^{\circ} \mathrm{C}$ at $10^{\circ} \mathrm{C} / \mathrm{min}$ and then to $160^{\circ} \mathrm{C}$ at $2{ }^{\circ} \mathrm{C} / \mathrm{min}$ for enantioselective GC-MS analyses.

Preparative GC isolation of $\mathbf{2}$ was carried out with a CE 4000 gas chromatograph, which was adapted for preparative work(16) and was fitted with a flame ionization detector and an on-column injector. A column coated with PS-255 (DB-1 equivalent) $(40 \mathrm{~m} \times 0.32 \mathrm{~mm}$, df $1.2 \mu \mathrm{m})$ was initially used for this preparative isolation, but a higher throughput was attained with a megabore column coated with the same phase $(32 \mathrm{~m} \times 0.53 \mathrm{~mm}$, df $2.0 \mu \mathrm{m})$, which was programmed from $40^{\circ} \mathrm{C}$ to $115^{\circ} \mathrm{C}$ at 2 ${ }^{\circ} \mathrm{C} / \mathrm{min}$ and then to $250^{\circ} \mathrm{C}$ at $10^{\circ} \mathrm{C} / \mathrm{min}$. Fractions were collected manually. Synthetic 2 was purified 
by preparative GC on a packed column ( $5 \mathrm{~m} \times 2.5 \mathrm{~mm}, 2.5 \% \mathrm{SE}-30$ on $60-80$ mesh Chromosorb). The column was programmed from $30^{\circ} \mathrm{C}$ to $150^{\circ} \mathrm{C}$ at $4{ }^{\circ} \mathrm{C} / \mathrm{min}$, and then to $250^{\circ} \mathrm{C}$ at $10^{\circ} \mathrm{C} / \mathrm{min}$.

Preparative enantioselective GC separation of the enantiomers of $\mathbf{2}$ was carried out on the above preparative GC using the above enantioselective column, which was programmed from $40{ }^{\circ} \mathrm{C}$ to 80 ${ }^{\circ} \mathrm{C}$ at $10^{\circ} \mathrm{C} / \mathrm{min}$ and then to $140{ }^{\circ} \mathrm{C}$ at $1{ }^{\circ} \mathrm{C} / \mathrm{min}$. The enantiomers were eluted as very broad peaks (column overloading) between $40^{\circ} \mathrm{C}$ and $140^{\circ} \mathrm{C}$.

\section{Germination Bioassay}

Germination activity of fractions and pure compounds was assessed using mature achenes (referred to as seeds) of Lactuca sativa L. cv. Grand Rapids (Peto Seed, Saticoy, CA). Seeds (25) were incubated for $24 \mathrm{~h}$ in the dark at $25^{\circ} \mathrm{C}$ in $65 \mathrm{~mm}$ plastic Petri dishes fitted with two sheets of $70 \mathrm{~mm}$ Whatman No. 1 filter paper and moistened with $2.2 \mathrm{~mL}$ of test solution. Distilled $\mathrm{H}_{2} \mathrm{O}$ served as a control. Manipulations with seeds were conducted in the dark under green "safelight".(10) Germination inhibitory activity of HPLC fractions was determined by testing $20 \mu \mathrm{L}$ of each $2 \mathrm{~mL}$ HPLC fraction in combination with $2.2 \mathrm{~mL}$ of a $0.01 \mu \mathrm{M}$ solution of 1 . The activity of synthesized compounds was tested using solutions containing a combination of $\mathbf{1}(0.001$ to $0.1 \mu \mathrm{M})$ and $\mathbf{2}(0.1$ to $100 \mu \mathrm{M})$. Singletreatment controls were also included. Experiments were carried out twice $(n=4)$. Germination data were arcsine transformed and analyzed using a one-way ANOVA and a Duncan's multiple range test, at a significance level of $P<0.05$. GenStat (Version 11) was used to conduct the analyses.

\section{Isolation of 3,4,5-Trimethylfuran-2(5H)-one}

Smoke-water was prepared by bubbling smoke from burned Passerina vulgaris Thoday and Themeda triandra L. through water. The smoke-water was concentrated, extracted with $\mathrm{CH}_{2} \mathrm{Cl}_{2}$, and subjected to $\mathrm{CC}$ as previously described.(3) Fractions with germination inhibitory activity ( $0 \%$ germination, fractions 33-45) from the column (Sephadex LH-20, $90 \times 2.5 \mathrm{~cm}$, eluted with $35 \% \mathrm{EtOH}$ at $15 \mathrm{~mL} / \mathrm{h}$ ) were combined and extracted with $\mathrm{CH}_{2} \mathrm{Cl}_{2}$. Purification was achieved by semipreparative HPLC. Active fractions, eluting between 14 and 16 min, were combined and extracted with $\mathrm{CH}_{2} \mathrm{Cl}_{2}$. Compound $\mathbf{2}$ was isolated as a racemate from this sample by preparative capillary GC: EIMS $m / z 126$ $\left(\mathrm{M}^{+}, 32\right), 111(12), 83(79), 55(100), 43(19), 39(20) ;{ }^{1} \mathrm{H}$ NMR $\left(400 \mathrm{MHz}\right.$, methanol- $\left.d_{4}\right) \delta 1.38(\mathrm{~d}, J=$ 6.7 Hz, 3H, Me-5), 1.77 (s, 3H, Me-4), 1.99 (s, 3H, Me-3), 4.91 (q, J = 6.7 Hz, 1H, H-5); ${ }^{13} \mathrm{C} \mathrm{NMR} \mathrm{(100}$ $\mathrm{MHz}$, methanol- $d_{4}$ ) $\delta 7.5$ (Me-3), 10.8 (Me-4), 17.1 (Me-5), 81.7 (C-5), 123.1 (C-3), 163.9 (C-4), 177.0 (C-2); GC-MS (EI) 126 (M+1 58), 111 (17), 83 (90), 55 (100), 53 (8), 43 (29), 39 (40).

\section{Synthesis of 1 and 2}

Karrikinolide (1) was synthesized from pyromeconic acid.(17) The original paper reported the yield as $22 \%$, but we obtained a yield at least 10 times lower.

Racemic 3,4,5-trimethylfuran-2(5H)-one (2) was synthesized according to a previous protocol(18) and purified by preparative $\mathrm{GC}$ to yield the target compound (99.9\% purity). The ${ }^{1} \mathrm{H}$ NMR spectroscopic data corresponded to those reported.(18) ${ }^{13} \mathrm{C} \mathrm{NMR}\left(600 \mathrm{MHz}, \mathrm{CDCl}_{3}\right) \delta 8.4(\mathrm{Me}-3)$, 11.7 (Me-4), 18.1 (Me-5), 79.5 (C-5), 122.8 (C-3), 160.3 (C-4), 174.4 (C-2). The MS data corresponded to those of the isolated compound 2. Preparative GC on the enantioselective column yielded pure samples $(0.5 \mathrm{mg} \pm 0.03 \mathrm{mg}$ ) of each of the two enantiomers in enantiomeric purities of $99 \%$ and $>97 \%$, respectively, which were tested as described above in combination with a $0.001 \mu \mathrm{M}$ solution of 1 . Results indicated that the enantiomers were equally active.

\section{Acknowledgment}

B.V.B., M.E.L., and J.V.S. were supported by the National Research Foundation of South Africa. Support for L.K. by the IOCB research project Z4 0550506 is gratefully acknowledged. Kirstenbosch National Botanical Gardens (South Africa) are thanked for their provision of smoke-water. 
Figures
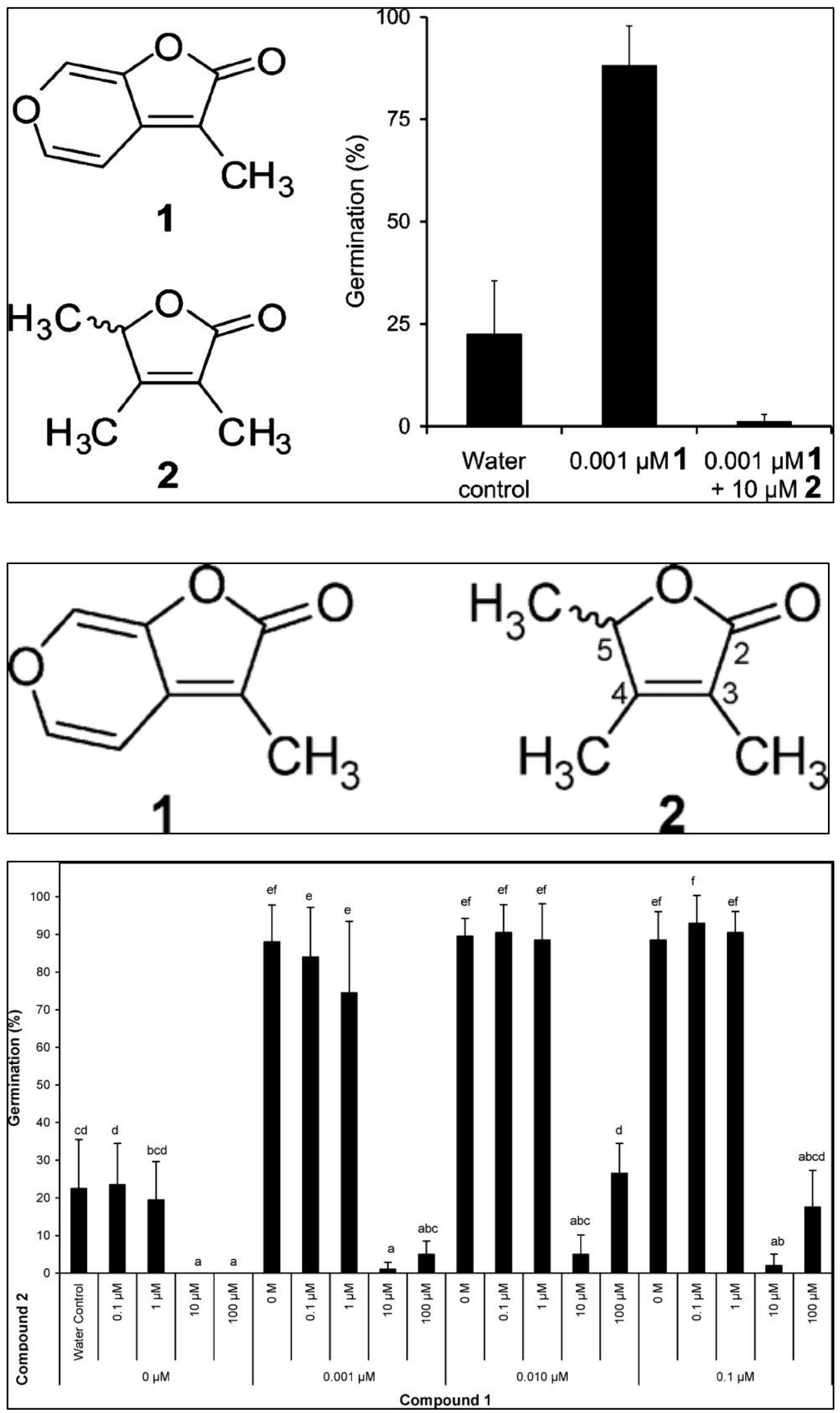

Figure 1 - Germination activity of test solutions on Grand Rapids lettuce seeds germinated in the dark at $25^{\circ} \mathrm{C}$ for $24 \mathrm{~h}$. Solutions contained a combination of compound $1(0.001$ to $0.1 \mu \mathrm{M})$ and compound $\mathbf{2}(0.1$ to $100 \mu \mathrm{M})$. Control was distilled water $(=0 \mathrm{M})$. Values are means of results from two separate experiments $\pm S D$. Bars with different letters indicate significant differences between treatments $(P<0.05)$ using Duncan's multiple range test $(\mathrm{df}$ between groups $=19$; residual $\mathrm{df}=140$; mean sum of squares between groups $=2.196$; residual mean sum of squares $=0.0280 ; F$-ratio $=78.502 ; P$-value $=<0.001)$ 


\section{References}

1. Van Staden, J., Brown, N. A. C., Jäger, A. K. and Johnson, T. A. Plant Species Biol. 2000, 15, $167-178$

2. Flematti, G. R., Ghisalberti, E. L., Dixon, K. W. and Trengove, R. D. Science 2004, 305, 977

3. Van Staden, J., Jäger, A. K., Light, M. E. and Burger, B. V. S. Afr. J. Bot. 2004, 70, 654- 659

4. Nelson, D. C., Riseborough, J.-A., Flematti, G. R., Stevens, J., Ghisalberti, E. L., Dixon, K. W. and Smith, S. M. Plant Physiol. 2009, 149, 863-873

5. Light, M. E., Daws, M. I. and Van Staden, J. S. Afr. J. Bot. 2009, 75, 1- 7

6. Chiwocha, S. D. S., Dixon, K. W., Flematti, G. R., Ghisalberti, E. L., Merritt, D. J., Nelson, D. C., Riseborough, J.-A. M., Smith, S. M. and Stevens, J. C. Plant Sci. 2009, 177, 252- 256

7. Dixon, K. W., Merritt, D. J., Flematti, G. R. and Ghisalberti, E. L. Acta Hort. 2009, 813, 155170

8. Soós, V., Juhász, A., Light, M. E., Van Staden, J. and Balázs, E. Seed Sci. Res. 2009, 19, 37-49

9. Soós, V., Sebestyén, E., Juhász, A., Pintér, J., Light, M. E., Van Staden, J. and Balázs, E. Funct. Integr. Genomics 2009, 9, 231- 242

10. Drewes, F. E., Smith, M. T. and Van Staden, J. Plant Growth Regul. 1995, 16, 205- 209

11. Lloyd, M. V., Dixon, K. W. and Sivasithamparam, K. Austral Ecol. 2000, 25, 610-615

12. Adkins, S. W. and Peters, N. C. B. Seed Sci. Res. 2001, 11, 213- 222

13. Daws, M. I., Davies, J., Pritchard, H. W., Brown, N. A. C. and Van Staden, J. Plant Growth Regul. 2007, 51, 73-82

14. Andreoli, C., Gigante, D. and Nunziata, A. Toxicol. in Vitro 2003, 17, 587- 594

15. Light, M. E., Gardner, M. J., Jäger, A. K. and Van Staden, J. Plant Growth Regul. 2002, 37, 135- 141

16. Burger, B. V., Viviers, M. Z., Bekker, J. P. I., le Roux, M., Fish, N., Fourie, W. B. and Weibchen, G. J. Chem. Ecol. 2008, 34, 659-671

17. Flematti, G. R., Ghisalberti, E. L., Dixon, K. W. and Trengove, R. D. Tetrahedron Lett. 2005, 46, 5719- 5721

18. Iwai, K., Kosugi, H., Uda, H. and Kawai, M. Bull. Chem. Soc. Jpn. 1977, 50, 242- 247 